\title{
Germination and hardseedness of seeds in okra elite lines
}

\author{
Luis Felipe V Purquerio ${ }^{1}$; Antonio A do Lago ${ }^{2}$; Francisco Antonio Passos ${ }^{1}$ \\ APTA-IAC, ${ }^{1}$ Centro de Horticultura, ${ }^{2}$ Núcleo de Negócios Tecnológicos, C. Postal 28, 13012-970 Campinas-SP, felipe@iac.sp.gov.br
}

\begin{abstract}
The occurrence of hardseedness and the low percentage of seed germination are major challenges when growing okra. For this reason, five elite lines of okra developed at the Campinas Agronomic Institute (IAC), three with angular pods (lines 8.1, 20.1.2 and 47.1) and two with cylindrical pods (lines 13.1.2 and 20.1.R), were evaluated for seed quality and compared to two commercial seed samples (Horticeres Sementes and Sakata Seed Sudamerica) of cultivar Santa Cruz 47. Seeds were field produced in an experiment set in the Technological Park of the Horticulture Center of IAC, in Campinas, São Paulo State, Brazil, in a randomized block design, with three replications and 20-plant plots. Fruits were harvested 25, $35,45,55,65$ and 75 days after anthesis (DAA). Seeds were extracted straight away and subjected to the standard germination test in the laboratory. Observing the results, we concluded that, as far as seed quality is concerned, angular pods must be harvested earlier than cylindrical pods, more precisely 45 DAA to the line 47.1 and 45 to 55 DAA for lines 8.1 and 20.1.2. Seeds extracted from angular fruits harvested after these periods had reduced germination and increased hardseedness. Seeds from cylindrical capsules had the same behavior of the commercial seeds of cultivar Santa Cruz 47, showing better germination when extracted from pods harvested between 55 and 75 DAA, and no hardseedness.
\end{abstract}

Keywords: Abelmoschus esculentus Moench, advanced generation lines, characterization, seed quality.

\section{RESUMO}

\section{Germinação e dureza de sementes em linhas elite de quiabo}

A presença de sementes duras e a baixa porcentagem de germinação são desafios importantes para o cultivo de quiabo. Por este motivo, cinco linhas elite de quiabo desenvolvidas no Instituto Agronômico de Campinas (IAC), sendo três com cápsulas quinadas (linhas 8.1, 20.1.2 e 47.1) e duas com cápsulas cilíndricas (linhas 13.1.2 e 20.1.R), foram avaliadas para qualidade de sementes, em comparação com dois lotes comerciais (Horticeres Sementes e Sakata Seed Sudamerica) de sementes da cultivar Santa Cruz 47. As sementes foram produzidas em experimento instalado no Parque Tecnológico do Centro de Horticultura do IAC, em Campinas, em blocos ao acaso, com três repetições e parcelas de 20 plantas. As cápsulas foram colhidas $25,35,45,55,65$ e 75 dias após a antese (DAA), sendo as sementes extraídas imediatamente e submetidas ao teste padrão de germinação em laboratório. Pelos resultados obtidos, concluiu-se que, no que diz respeito à qualidade das sementes, cápsulas quinadas devem ser colhidas mais precocemente que cápsulas cilíndricas, mais precisamente 45 DAA para a linha 47.1 e de 45 a 55 DAA para as linhas 8.1 e 20.1.2. Sementes extraídas de cápsulas quinadas colhidas após esses períodos apresentaram redução na germinação e aumento no índice de dureza. Já as sementes provenientes de cápsulas cilíndricas apresentaram comportamento semelhante às sementes da cultivar Santa Cruz 47, apresentando melhor capacidade germinativa quando provenientes de cápsulas colhidas de 55 a 75 DAA, e ausência de dureza.

Palavras-chave: Abelmoschus esculentus Moench, linhas de geração avançada, caracterização, qualidade de sementes.

(Recebido para publicação em 12 de março de 2009; aceito em 20 de abril de 2010)

(Received on March 12, 2009; accepted on April 20, 2010)

$\mathrm{O}$ $\mathrm{kra}$, a vegetable adapted to tropical and subtropical climates and with low production costs, is widely cultivated in Brazil, especially by small farmers. Production figures for the State of São Paulo show that okra is cultivated in $1,523.82$ ha, resulting in 22,462 $\mathrm{t}$ (IEA, 2005), which are almost exclusively driven to small grocery stores. The most commonly grown cultivars are Colhe Bem and Santa Cruz 47. Both cultivars have round pods, although angular pods are preferred by the foreign market. Therefore, to progress towards increasing okra exports, it is necessary to implement changes in our production system, including the adaptation of cultivars with angular pods to our climate. Looking simultaneously at the internal and external markets, the
Agronomic Institute of Campinas (IAC) developed five okra elite lines, three with angular pods (lines 8.1, 20.1.2 and 47.1) and two with round pods (lines 13.1.2 and 20.1.R) (Passos et al., 2003). These five lines are presently in the characterization phase for registration in the Ministry of Agriculture, Livestock and Food Supply.

There are two techniques to produce okra seeds (Setubal et al., 1996). The most used in USA is based on the single harvest of morphologically mature pods, in senescent plants. The other technique, common to regions of high air temperature and moisture like Brazil, includes the periodical harvest of mature pods, which increases the cost of seed production in comparison to the previous method. Regardless of the production process, the percentage of seed germination in okra is frequently low, due to tegument impermeability (hard seeds). This is the major barrier to the emergence of commercial producers of okra seeds (Castro, 2005).

There are differences among the okra cultivars used in Brazil in relation to hardseedness, resulting in lack of uniformity in seed germination (Castro, 2005). In some cultivars, the occurrence of hard seeds becomes more frequent the longer the pods remain in the plant (Viggiano, 1991). Concerning hardseedness, the okra cultivars used in Brazil differ as follows: pods of cultivar Amarelinho can be harvested only once, because it does not present hardseedness, while in cultivars Santa Cruz 47 and especially cultivar Campinas-2, the 
harvest time is critical for seed quality (Setúbal et al., 1994).

Pod position in the plant also affects seed quality. Pereira (1975) verified that seeds from pods located in the middle of the plant presented higher germination capacity than those extracted from pods located in plant ends and ramifications. Looking for information about pod maturation, Setubal et al. (1994) concluded that, regarding seed production, the most adequate stage for pod harvesting is between 45 and 55 days after anthesis (DAA) for cultivars Campinas-2, Santa Cruz 47 and Amarelinho. In the case of cultivar Santa Cruz 47, Castro (2005) observed that seed quality decreased in pods harvested between 34 and 41 DAA without a post harvest resting period.

The aim of this work was to evaluate the seed quality of five IAC okra elite lines in comparison to two commercial samples of cultivar Santa Cruz 47.

\section{MATERIAL AND METHODS}

The experiment was carried out in the Technological Park of the Horticulture Center of the Agronomic Institute of Campinas (IAC), located in Campinas, to evaluate the germination capacity and the hardseedness in okra seeds. We used completely randomized blocks, with three replications and 20-plant $4 \mathrm{~m}$ long plots. Treatments corresponded to five okra elite lines developed by IAC, three with angular pods (lines 8.1, 20.1.2 and 47.1 ) and two with round pods (lines
13.1.2 and 20.1.R), and cultivar Santa Cruz 47, using seed samples from two companies, namely Horticeres Sementes and Sakata Seed Sudamerica.

Soil characteristics were: $\mathrm{pH}$ 5.8; 28 $\mathrm{mmol}_{\mathrm{c}} \mathrm{dm}^{-3}$ of $\mathrm{H}+\mathrm{Al} ; 114 \mathrm{mg} \mathrm{dm}^{-3}$ of P; $1.6 \mathrm{mmol}_{\mathrm{c}} \mathrm{dm}^{-3}$ of $\mathrm{K} ; 49 \mathrm{mmol}_{\mathrm{c}} \mathrm{dm}^{-3}$ of $\mathrm{Ca} ; 16 \mathrm{mmol}_{\mathrm{c}} \mathrm{dm}^{-3}$ of $\mathrm{Mg}$; SB 65.6 $\mathrm{mmol}_{\mathrm{c}} \mathrm{dm}^{-3}$; CEC $93.4 \mathrm{mmol}_{\mathrm{c}} \mathrm{dm}^{-3}$; $\mathrm{V}(\%) 70 \mathrm{mmol}_{\mathrm{c}} \mathrm{dm}^{-3}$; Organic Matter $28 \mathrm{~g} \mathrm{dm}^{-3} ; 8.5 \mathrm{mg} \mathrm{dm}^{-3}$ of $\mathrm{Cu} ; 23 \mathrm{mg}$ $\mathrm{dm}^{-3}$ of Fe; $24.9 \mathrm{mg} \mathrm{dm}^{-3}$ of Mn and 3.6 $\mathrm{mg} \mathrm{dm} \mathrm{m}^{-3}$ of $\mathrm{Zn}$.

Okra seedlings were produced in 72-cell expanded polystyrene trays containing commercial substrate (Plantmax HT). Seedlings were transplanted on December 28, 2004, with 3 to 4 true leaves, into $1.0 \times 0.2 \mathrm{~m}$ spacing. Both fertilizations (at planting and side dressing) followed the results of soil analysis, according to the fertilizer and liming recommendations for okra in the State of São Paulo (Trani \& Raij, 1996). Soil was prepared using a rotary tiller.

Okra flowers in the lower third of each plant were identified and tagged at anthesis. Pods were harvested 25, $35,45,55,65$ and 75 days after anthesis (DAA) and seeds were extracted soon after harvesting. Seed moisture was determined after 24 hours in a drying oven, at $105 \pm 3^{\circ} \mathrm{C}$ for $24 \mathrm{~h}$ (Brasil, 1992). Following, seeds were submitted to the standard germination test in the Seed Analysis Laboratory of IAC, according to Standards for Seeds Analysis (Brasil, 1992), using 50-seed replications.
Germination capacity and hardseedness were evaluated at 4, 7, 14, 21 and 28 days after the beginning of the tests.

We performed analysis of variance ( $F$ test) and Tukey's test $(\mathrm{p}<0,05)$ for mean comparison. Percentages were transformed into $\arcsin \sqrt{\% / 100}$ before analysis.

\section{RESULTS AND DISCUSSION}

Seed germination and hardseedness in the okra elite lines and also in both commercial seed samples of cultivar Santa Cruz 47 changed as a function of the time of pod harvesting (25 to 75 DAA) (Figures 1A and 1B). Seeds taken from pods harvested at 25 and 35 DAA did not germinate due to their incomplete development; seeds also showed high moisture content in these periods (Table 1).

Seed moisture, independently of the genotype, decreased from 25 to 75 DAA (Table 1), with a steep decline from 35 to 45 DAA. Setúbal et al. (1996) observed $10.1 \%$ of moisture in seeds of cultivar Santa Cruz 4745 DAA, a figure close to that found currently (14.1\%), at the same evaluation time. Angular pods started dehiscing 55 DAA and, consequently, seeds were exposed to the environment. This fact may have contributed to accelerate the decrease in moisture in seeds from angular in comparison to those from round pods (Table 1). However, at 65 DAA, seed moisture was statistically the same for all genotypes,

Table 1. Moisture content of okra seeds extracted from pods harvested 25, 35, 45, 55, 65 and 75 days after anthesis (teor de umidade de sementes de quiabo extraídas de cápsulas colhidas 25, 35, 45, 55, 65 e 75 dias após a antese). Campinas, IAC, 2005.

\begin{tabular}{|c|c|c|c|c|c|c|c|}
\hline \multirow{2}{*}{ Genotype } & \multirow{2}{*}{ Pod shape } & 25 DAA & 35 DAA & 45 DAA & 55 DAA & 65 DAA & 75 DAA \\
\hline & & \multicolumn{6}{|c|}{$(\%)$} \\
\hline $\mathrm{S}^{\text {ta }}$. Cruz $47^{2}$ & Round & $63.0 \mathrm{a}$ & $54.0 \mathrm{a}$ & $13.7 \mathrm{a}$ & $12.9 \mathrm{a}$ & $12.0 \mathrm{a}$ & $12.3 \mathrm{a}$ \\
\hline $\mathrm{S}^{\text {ta }}$. Cruz $47^{3}$ & Round & $63.9 \mathrm{a}$ & $53.8 \mathrm{a}$ & $14.6 \mathrm{a}$ & $12.4 \mathrm{ab}$ & $12.1 \mathrm{a}$ & $11.7 \mathrm{ab}$ \\
\hline 20.1.R & Round & $64.4 \mathrm{a}$ & $53.2 \mathrm{a}$ & $14.4 \mathrm{a}$ & $12.2 \mathrm{ab}$ & $11.5 \mathrm{a}$ & $11.5 \mathrm{ab}$ \\
\hline 13.1 .2 & Round & $63.8 \mathrm{a}$ & $54.3 \mathrm{a}$ & $13.1 \mathrm{a}$ & $12.3 \mathrm{ab}$ & $11.5 \mathrm{a}$ & $10.5 \mathrm{~b}$ \\
\hline 20.1 .2 & Angular & $61.9 \mathrm{a}$ & $52.3 \mathrm{a}$ & $13.3 \mathrm{a}$ & $10.5 \mathrm{~b}$ & $9.4 \mathrm{a}$ & $9.4 \mathrm{~b}$ \\
\hline 8.1 & Angular & $61.5 \mathrm{a}$ & $48.1 \mathrm{a}$ & $11.5 \mathrm{a}$ & $10.3 \mathrm{~b}$ & $8.9 \mathrm{a}$ & $8.4 \mathrm{~b}$ \\
\hline 47.1 & Angular & $60.5 \mathrm{a}$ & $49.4 \mathrm{a}$ & $12.4 \mathrm{a}$ & $9.6 \mathrm{~b}$ & $8.1 \mathrm{a}$ & $8.9 \mathrm{~b}$ \\
\hline $\mathrm{CV}(\%)$ & & 0.0 & 0.0 & 7.7 & 8.1 & 10.1 & 13.2 \\
\hline
\end{tabular}

Means followed by same letter in the column did not differ significantly from each other, Tukey test, $\mathrm{p}<0.05$ (médias seguidas de mesma letra na coluna não diferem significativamente entre si, teste de Tukey, $\mathrm{p}<0,05) ;{ }^{1} \mathrm{DAA}=$ days after anthesis (dias após a antese); ${ }^{2} \mathrm{Seeds}$ from Sakata Seed Sudamerica (sementes da Sakata Seed Sudamerica); ${ }^{3}$ Seeds from Horticeres Sementes (sementes da Horticeres Sementes). 

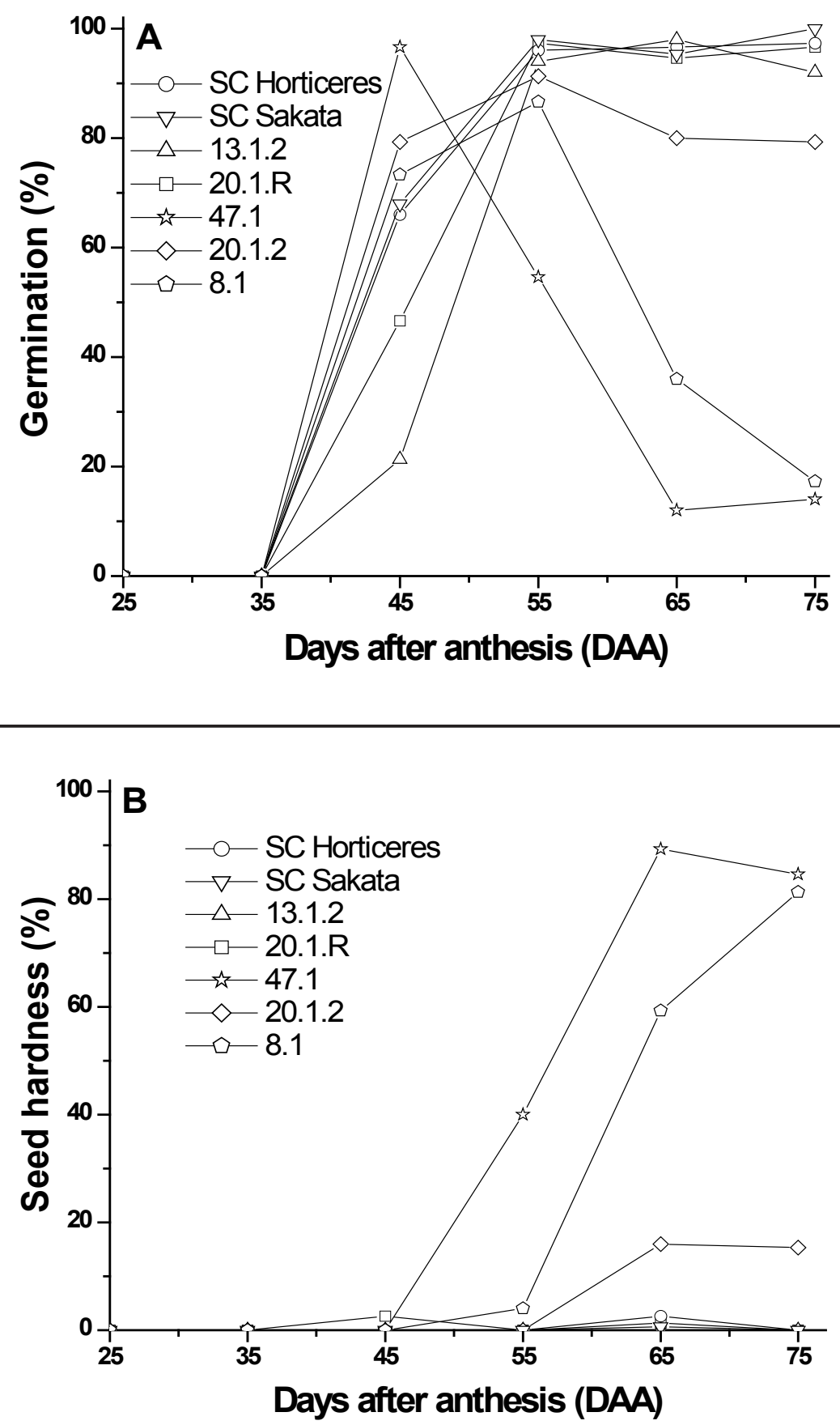

Figure 1. Germination percentage (A) and hardseedness (B) of okra seeds as affected by the time of pod harvesting (porcentagem de germinação e dureza em sementes de quiabo em função da época de colheita das cápsulas). Campinas, IAC, 2005.

invalidating the hypothesis that seeds from dehiscent pods (angular) have lower moisture. At the last evaluation date, 75 DAA, genotypes differed little in seed moisture, but the differences bore no relation with pod morphology.

Germination started occurring only in seeds harvested from 45 DAA ahead
No hardseedness was observed at this point.

Seeds of lines with angular pods showed higher germination capacity soon after harvesting than later. In addition, with seed aging (increase in time after anthesis) the germination capacity decreased as hardseedness increased (Table 3). Seeds of line 47.1 (angular pods) showed an abrupt reduction in the germination percentage $55 \mathrm{DAA}$, merely $56 \%$, and the line differed significantly from the others (Table 2). As seeds aged, the germination percentage of lines 47.1 and 8.1, both with angular pods, continued decreasing, getting as low as 11 and $37 \%$, respectively, 65 DAA. Seeds of line 20.1.2, also with angular pods, showed a decrease in germination too. However, seed germination in line 20.1.2 obeyed the pattern observed in lines with round pods and, up to 65 DAA, did not differ significantly from them.

Seeds of lines 47.1 and 8.1, with angular pods, showed the lowest germination percentage and highest hardseedness 75 DAA (Tables 2 and 3). Line, 20.1.2, also with angular pods, although presenting decrease in germination and increase in hardseedness, expressed them in a much lesser degree than the other lines with angular pods. No hardseedness was observed among lines with round pods in any stage of development, in agreement with Setubal et al. (1994), who did not find hardseedness in cultivar Santa Cruz 4755 DAA.

Observing the results, we concluded that, as far as seed germination is concerned, angular pods must be harvested earlier than round pods, namely 45 DAA for line 47.1 and from 45 to 55 DAA for lines 8.1 and 20.1.2. After this stage, seed germination falls, as hardseedness increases. Seeds of round selections stabilized their germination rate above $95 \%$ at 55 DAA and kept at this level up to 75 DAA. Therefore, we suggest round pods to be harvested within this period. For these lines, it is not advisable to use the method of a single harvest described by Setúbal et al. (1994). Cultivar Santa Cruz 47, independent of seed origin, presented better seed quality when seeds 
Table 2. Germination (\%) of okra seeds extracted from pods harvested 45, 55, 65 and 75 days after anthesis (germinação (\%) de sementes de quiabo extraídas de cápsulas colhidas 45, 55, 65 e 75 dias após a antese). Campinas, IAC, 2005.

\begin{tabular}{|c|c|c|c|c|c|}
\hline \multirow{2}{*}{ Genotype } & \multirow{2}{*}{$\begin{array}{c}\text { Pod } \\
\text { shape }\end{array}$} & 45 DAA & 55 DAA & $65 \mathrm{DAA}$ & 75 DAA \\
\hline & & \multicolumn{4}{|c|}{$(\%)$} \\
\hline $\mathrm{S}^{\text {ta }} \cdot \mathrm{Cruz} 47^{2}$ & Round & $73 a b^{1}$ & $98 \mathrm{a}$ & $97 \mathrm{a}$ & $100 \mathrm{a}$ \\
\hline $\mathrm{S}^{\text {ta }} \cdot \mathrm{Cruz} 47^{3}$ & Round & $71 \mathrm{ab}$ & $97 \mathrm{a}$ & $97 \mathrm{a}$ & $97 \mathrm{a}$ \\
\hline 20.1.R & Round & $67 \mathrm{ab}$ & $99 \mathrm{a}$ & $97 \mathrm{a}$ & $97 \mathrm{a}$ \\
\hline 13.1 .2 & Round & $27 \mathrm{~b}$ & $95 \mathrm{a}$ & $98 \mathrm{a}$ & $97 \mathrm{a}$ \\
\hline 20.1 .2 & Angular & $87 \mathrm{ab}$ & $96 \mathrm{a}$ & $82 \mathrm{a}$ & $80 \mathrm{~b}$ \\
\hline 8.1 & Angular & $95 \mathrm{a}$ & $91 \mathrm{a}$ & $37 \mathrm{~b}$ & 17 \\
\hline 47.1 & Angular & $99 \mathrm{a}$ & $56 \mathrm{~b}$ & $11 \mathrm{c}$ & 14 \\
\hline CV (\%) & & 24.4 & 8.4 & 9.6 & 9.4 \\
\hline
\end{tabular}

Means followed by same letter in the column did not differ significantly from each other, Tukey test, $p>0.05$ (médias seguidas de mesma letra na coluna não diferem significativamente entre si, teste de Tukey, $\mathrm{p}>0,05) ;{ }^{1} \mathrm{DAA}=$ days after anthesis (dias após a antese); ${ }^{2}$ Seeds from Sakata Seed Sudamerica (sementes da Sakata Seed Sudamerica); ${ }^{3}$ Seeds from Horticeres Sementes (sementes da Horticeres Sementes).

Table 3. Hardseedness (\%) in okra seeds extracted from pods harvested 55, 65 and 75 days after anthesis (sementes duras (\%) em sementes de quiabo extraídas de cápsulas colhidas 55, 65 e 75 dias após a antese). Campinas, IAC, 2005.

\begin{tabular}{llccc}
\hline \multirow{2}{*}{ Genotype } & Pod shape & $\mathbf{5 5} \mathbf{D A} \mathbf{A}^{\mathbf{1}}$ & $\mathbf{6 5} \mathbf{D A A}^{\mathbf{1}}$ & $\mathbf{7 5 ~} \mathbf{D A}^{\mathbf{1}}$ \\
\cline { 3 - 5 } & & $0 \mathrm{~b}$ & $\mathbf{( \% )}$ & \\
\hline $\mathrm{S}^{\text {ta }} \cdot$ Cruz $47^{2}$ & Round & $0 \mathrm{~b}$ & $1 \mathrm{~d}$ & $0 \mathrm{c}$ \\
$\mathrm{S}^{\text {ta }}$ Cruz $47^{3}$ & Round & $0 \mathrm{~b}$ & $1 \mathrm{~cd}$ & $0 \mathrm{c}$ \\
$20.1 . \mathrm{R}$ & Round & $0 \mathrm{~b}$ & $0 \mathrm{~d}$ & $0 \mathrm{c}$ \\
13.1 .2 & Round & $0 \mathrm{~b}$ & $16 \mathrm{c}$ & $0 \mathrm{c}$ \\
20.1 .2 & Angular & $4 \mathrm{~b}$ & $59 \mathrm{~b}$ & $81 \mathrm{a}$ \\
8.1 & Angular & $40 \mathrm{a}$ & $89 \mathrm{a}$ & $85 \mathrm{a}$ \\
47.1 & Angular & 109.8 & 30.2 & 21.9 \\
\hline $\mathrm{CV}(\%)$ & &
\end{tabular}

Means followed by same letter in the column did not differ significantly from each other, Tukey test, $\mathrm{p}>0.05$ (médias seguidas de mesma letra na coluna não diferem significativamente entre si, teste de Tukey, $\mathrm{p}>0,05) ;{ }^{1} \mathrm{DAA}=$ days after anthesis (dias após a antese); ${ }^{2}$ Seeds from Sakata Seed Sudamerica (sementes da Sakata Seed Sudamerica); ${ }^{3}$ Seeds from Horticeres Sementes (sementes da Horticeres Sementes). were extracted from pods harvested from 55 DAA ahead, confirming the results obtained by Castro (2005).

\section{REFERENCES}

BRASIL. 1992. Regras para análise de sementes. Brasília: SNDA/DNDV/CLAV. 365p.

CASTRO MM. 2005. Qualidade fisiológica de sementes de quiabeiro em função da idade e do repouso pós-colheita dos frutos. Botucatu: FCA, UNESP. 43p (M.Sc. thesis).

IEA. 2005. Banco de dados IEA. São Paulo. Available in: www.iea.sp.gov.br. Accessed in February 7, 2007.

PASSOS FA; MELO AMT; AZEVEDO FILHO JA; RIBEIRO IJA; FOLTRAN DE. 2003. Novas seleções IAC de quiabo para o mercado interno e exportação. In: ENCONTRO SOBRE TEMAS DE GENÉTICA E MELhoramento. Proceedings... Piracicaba: ESALQ/USP, p.141.

PEREIRA AL. 1975. Efeito da idade do fruto e sua localização na planta sobre a qualidade das sementes de quiabeiro (Abelmoschus esculentus). Viçosa: Universidade Federal de Viçosa. 51p. (M.Sc. thesis).

SETUBAL JW; ZANIN ACW; NAKAGAWA J. 1994. Efeitos de métodos de colheita e da localização dos frutos na planta sobre a ocorrência de sementes duras em quiabeiro (Abelmoschus esculentus (L.) Moench). Scientia Agricola 51: 490-493.

SETUBAL JW; ZANIN ACW; NAKAGAWA J. 1996. Efeitos da idade dos frutos, método e condição de secagem sobre a qualidade de sementes de quiabeiro (Abelmoschus esculentus L. Moench) cv. Santa Cruz-47. Revista Brasileira de Sementes 18: 138-142.

TRANI PE; RAIJ B. 1996. Hortaliças. In: RAIJ B (ed). Recomendações de adubação e calagem para o estado de São Paulo. 2 ed. Campinas: IAC, p.157-186, (Boletim técnico 100).

VIGGIANO J. 1991. Situação da produção de sementes de hortaliças. In: ENCONTRO SOBRE PRODUÇÃO E QUALIDADE DE SEMENTES DE HORTALIÇAS. Proceedings... Brasilia: CNPH. 151p. 